\title{
通常歩行時の骨盤加速度に注目した歩行分析
}

一若年者における歩行時加速度の特徵的パターンの同定に関する検討一

\section{Identifying the Characteristic Acceleration Patterns by Using Accelerographic Analysis of the Pelvis in Normal Working}

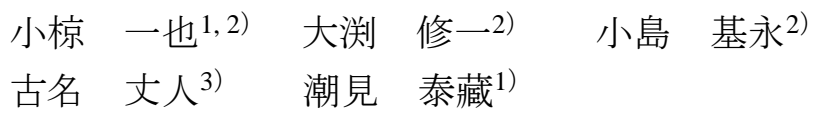

KAZUYA OGURA ${ }^{1,2)}$, SHUICHI OBUCHI'), MotONAGA KOJIMA ${ }^{2)}$, TAKETO FURUNA ${ }^{3)}$, TAIZO SHIOMI ${ }^{1)}$
1) International University of Health and Welfare Graduate School: 2600-1 Kitakanemaru, Otawara-shi, Tochigi 324-8501,
Japan. TEL + 81 287-24-3100
2) Department for Prevention of Dependence on Long-term Care, Tokyo Metropolitan Institute of Gerontology
3) Department of Physical Therapy, School of Allied Health Professions and School of Health Sciences, Sapporo Medical University

Rigakuryoho Kagaku 20(2): 171-177, 2005. Submitted Dec. 21, 2004. Accepted Mar. 8, 2005.

ABSTRACT: Using an accelerograph for objective evaluation of gait is a focus of attention, but the characteristic pattern for a basic index is not clear. In this study, we aimed to identify a common characteristic pattern from the normalized acceleration data of young people. An accelerometer was attached to the sacrum of pelvis and 3 different directions, back to front (X-axis), right and left (Y-axis) and above and below (Z-axis), were measured for 20 young people during normal walking. The acceleration pattern was extracted after normalizing the data to study the characteristic points. Among the same subjects, the characteristic pattern of acceleration in each direction showed a definitive tendency. In the mean data of 20 people, only X-axis showed the reflection of individual characteristics. Furthermore, in the Z-axis, the individual characteristic pattern was also reflected, but within the same subject group, the scatter tended to be regular so it was not necessarily evident in the data of 20 people. From the above results, in the pelvic acceleration of healthy young persons in walking, a characteristic pattern exists which has in common average values of the group as a whole as well as individual subjects.

Key words: gait analysis, acceleration, characteristic pattern

要旨: 歩行の客観的評価に加速度計を用いる方法が注目されているが, 基準指標となる特徵的パターンは明らかにさ れていない。そこで本研究は, 正規化した若年者の歩行時加速度データより共通する特徵的パターンを同定すること を目的とした。若年者99名の通常歩行時の加速度計を骨盤の仙骨部に装着し, 前後方向 (X軸), 左右方向 (Y軸), 上 下方向（Z軸）の3方向において計測した。無作為に20名を抽出し，データを正規化して加速度パターンの抽出から特 徵点を検討した。同一対象者内では各方向とも加速度の特徵的パターンは一定となる傾向を示した。20名のデータの 平均值については前後方向だけが個人の特徵を反映するパターンを示した。また，上下方向においても同様に個人の 特徵的パターンを反映していたが，同一対象者内では分散は一定となる傾向を示したものの，20名のデータでは必ず しも一定とはならなかった。以上の結果から, 健常若年者による歩行時の骨盤加速度には対象者個人および対象者全 体の平均值に共通した特徵的なパターンが存在することが明らかとなった。

キーワード : 歩行分析, 加速度, 特徵的パターン

1) 国際医療福祉大学大学院 医療福祉学研究科：杤木県大田原市北金丸2600-1 ( ( 324-8501) TEL 0287-24-3100（代)

2) 東京都老人総合研究所 介護予防緊急対策室 3) 札幌医科大学 保健医療学部理学療法学科

受付日 2004年12月21日＼cjkstart受理日２005年3月8日 


\section{I. 緒 言}

歩行分析に関する研究では，これまで主として歩行速 度や歩行率あるいは床反力などの運動学的および運動力 学的パラメータによる測定や，エネルギー効率等の生理 学的指標を用いた評価等が行われてきた。一般に，歩行 能力は速度, 耐久性, 安定性（バランス）等から評価さ れるが，歩行時の安定性について標準化された客観的評 価方法は存在しない。昨今では，高齢者における歩行中 の転倒事故が問題視されるが，歩行時の安定性を関節角 度変化による分析から判断することは難しく, より精度 の高い，有用な測定法の開発が必要であると指摘されて (る ${ }^{1)}$ 。歩行の安定性には円滑性や再現性・動摇性・対称 性などが関与すると報告されている22が, その評価は観察 者の主観に基づくものであることが多いため, 客観的指 標評価法が必要性となる。近年, 加速度計を用いた分析 法が行われており，測定が簡便かつ臨床応用が広く可能 であり ${ }^{3)}$, 被験者への拘束や実施環境の制限が少なく多数 歩計測が可能である，という理由から注目されている4)。 歩行時における加速度測定の意義は，得られる加速度 データから正常歩行パターンとしての安定性, すなわち, 歩行動作の円滑性を客観的に判断できるということであ る。加速度は質量が一定の場合，歩行中に必要とされる 「力」に比例するため, 歩行時の加速度の時間的な変化か ら“力の安定性”を客観的に観察することが可能である。 もし重心点に加速度計を装着できれば歩行中に身体にか かる「力」の時間的変化を示すことができる。従って, その加速度の変化值である波形から, 正常歩行パターン からの逸脱の度合いを判断することができるものと推測 される。これを基準として用いれば歩行の安定性あるい は不安定性を客観的に評価しうるものと考えられる。

加速度計による歩行の安定性・不安定性の分析を試み た研究は1960年代より始まり5)，その後，より精度の高 い装置が開発され, 不安定性に関して正常歩行パターン から逸脱した要素の抽出が試みられている6)。また，田 中ら ${ }^{3)}$ は歩行時の体幹動摇性を客観的に評価する方法と して健常成人を対象に加速度を測定した結果，良好な再 現性を有していると報告しており，窪田ら7)も片麻痺患 者の歩行能力の安定性に関する客観的評価方法として加 速度の計測を用いている。これらの先行研究の結果を総 合すると，加速度測定による歩行分析によって，（1）他 の歩行分析法と併用して個人の歩行に関する特徴につい て，より客観的に判断され，(2) 個人における歩行の特 徵を抽出することが可能であると推測される。しかし， これまでの先行研究では歩行時加速度の安定性, 不安定
表1 分析対象者の属性

\begin{tabular}{ccccc}
\hline 性別 & 人数 & 平均年齢 $($ 歳 $)$ & 平均身長 $(\mathrm{cm})$ & 平均体重 $(\mathrm{kg})$ \\
\hline 男性 & 8 & $20.4 \pm 3.3$ & $171.3 \pm 8.3$ & $64.7 \pm 10.7$ \\
女性 & 12 & $21.0 \pm 4.0$ & $160.0 \pm 7.1$ & $55.9 \pm 5.4$ \\
\hline
\end{tabular}

あるいは異常性を検出するにとどまっており，通常歩行 における加速度の基準指標となる特徵的パターンについ ては必ずしも十分検討されていない。そこで，本研究で は健常若年者を対象として, 歩行時の加速度に共通した 特徵的パターンを同定することが可能か否かについて検 討した。

\section{II. 方 法}

1. 対象者

健常学生99名を若年者群とした。本研究において加速 度データを視覚的分析法により分析するため, 先行研究8) にならい情報処理能力の限界数を 20 例とした。20例の選 出は, 99名の対象者の中から無作為に20名抽出した。対象 者の属性を表1に示す。

なお，対象者の条件として，過去および現在において 整形外科学的な疾患の既往のないこととした。

\section{2. 使用機器}

加速度計はある点に生じる加速度を電圧值に変換する 変換機（トランスデューサ）と増幅器から構成されてい る。

本研究の測定では測定範囲土25 G, 感度 $5 \mathrm{mV} / \mathrm{G}$ 以上, 寸法 $15 \times 12 \times 20 \mathrm{~mm}$, 重量 $12.5 \mathrm{~g}$ の3軸加速度計（加速度 トランデューサTA-513G／日本電光）を使用した。加速度 トランスデューサの信号を送信機のヘッドアンプで増幅 し，受信機へと転送するために，テレメータシステム (マ ルチテレメータシステムWEB-5000／日本電光）を用い, そのデータを記録し，コンピュータへ転送する目的で データレコーダ（PCMデータレコーダPC208／SONY）と データ収集ソフトウェア（PCスキャンMKII PCIF250EP/ $\mathrm{NI}$ ／SONY）を用いた。加速度計の校正には，動ひずみ測 定器（YB504-A／共和電業）を用いた。

\section{3. 測定方法}

測定条件を統一寸るために，被験者は同じタイプの運 動靴を着用した。測定前に動歪み測定器を用いて $1 \mathrm{~V}=1 \mathrm{G}$ で加速度計を校正した後, 3軸加速度計を身体の重心点と みなし，仙骨部（第2仙椎）に着衣の上からベルトで固定 
した。

なお，加速度計の縦軸の方向を以下のように定義する こととした。

3軸加速度計

X軸（前後方向） 前方向への加速度 : + 後方向への加速度 : -

Y軸（左右方向）左方向への加速度 : + 右方向への加速度 : -

Z軸（上下方向）下方向への加速度 : + 上方向への加速度 : -

被験者は加速度計を装着し, 助走路 $3 \mathrm{~m}$, 測定区間 10 $\mathrm{m}$, 予備路 $3 \mathrm{~m}$ の直線歩行路を各自の自由な速さで歩くこ ととし，この間の加速度ならびに歩行時間をストップ ウオッチで計測した。また，各被検者ごとの歩行計測の 実施は1回とした。

骨盤での加速度を測定するために3軸加速度計を用い, テレメータシステムでデータを送信，データレコーダに 記録した。このデータをデータ収集ソフトウェアにより コンピュータに転送し処理した。

\section{4. 解析方法}

データレコーダに記録したデータ（デジタルデータ） は，サンプリング周波数 $24,000 \mathrm{~Hz}$ でコンピュータに保存 した。その後 $500 \mathrm{~Hz}$ のバターワースフィルタをかけた後 24,000 Hzから1,000 Hzに間引きした。

連続歩行のデータを 1 歩行周期ごとに切り出し, それぞ れ100 HzのFIRフィルタを用いて平滑化処理した。歩行周 期ごとにデータ数が異なるため, 補間処理を行い, 1 歩行 周期分が 1,000 点になるように正規化した。

基本統計量の処理は表計算ソフト (Excel2000/Microsoft) を用いた。正規化した5歩行周期分を平均し，標準偏差： Standard deviation（以下, SD）を求めた。

\section{5. 評価方法}

(1) 記載する加速度データのグラフ

加速度データを図示するにあたってのグラフは, 左足 の踵接地（以下， HC）から1歩行周期に切り出しをした もので, 縦軸は加速度の大きさ（単位：G）を示してお り, その方向は前後方向 (X軸), 左右方向 ( $\mathrm{Y}$ 軸), 上下 方向 (Z軸) の3軸により異なる (II-3. 参照)。横軸は左足 を起点として 1,000 点に正規化したデータを\%（パーセン 卜）歩行周期：\%gait cycle（以下，\%GC）として示した。

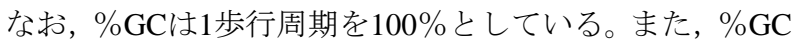
を基準とした時間比率をタイミングとする。

左足を起点とした1歩行周期の切り出しにあたっては,
まず，左右方向の加速度データから左足の加速度ピーク 值にあたる歩行周期の值を切り出し点の起点とした。対 象となる5歩行周期分の值を前後方向, 上下方向に当ては めた。なお，通常歩行状態を抽出するために歩き始めか ら4歩行周期以降の加速度データを対象とした。

(2) 加速度データの分析

加速度データの分析は，各対象者の示寸波形線の軌跡 に対し，大きさ $(\mathrm{G})$ ，タイミング (\%GC) から特徴パ ターンを確認する。着眼する点は先行研究8-10)を参考に図 1に示寸分析ポイント（a）から（f）までとする。

〔照合する分析ポイント〕

(a) 振幅の大きさ : 左の踵接地 : heel contact (以下, HC) 前後における振幅の大きさ。

(b) 右足振幅ピークタイミング : 右の十（プラス）ピー クとその手前に示されるー (マイナス) ピークの位 置までの地点。右HCから右の踵離地 : heel off（以 下，HO）にあたり，対象者内の加速度変化を大き く示寸部分。

(c) 左右差 : 1歩行周期のデータを半分に分け重社たと きの左右対称性 (最大振幅出現までの時間差のずれ による左右差)。

(d) 30\%歩行周期分散 : 30\%歩行周期地点の対象者内分 散の大きさ。ここは左のHOの後方にあたり，対象 者内分散が全歩行周期を通して最も安定している 部分。

(e) 15 30\%歩行周期加速度変化 : 対象者内の5歩行周 期分の平均值について，加速度変化の大きさをみ る。ここは右の足先離地 : toe off（以下，TO）の後 方から左HOの後方に当たり, 対象者内平均加速度 変化が全歩行周期を通して最も安定している部分。

(f) 減速タイミング：0\%歩行周期を起点に左足の加速 度ピークを経て，再び加速度の大きさが $0 \mathrm{G}$ 戻る タイミング。

\section{III. 結 果}

1. 対象者別による分析

対象となる20例の加速度データを3方向分全て分析し た。無作為に抽出された3名のデータ（対象者A, B, C) を 図2に示す。この図は抽出した対象者の加速度データ5歩 行周期分を 3 方向別に平均值とSDを示したものである。

3方向とも若年者の歩行時加速度は各対象者内のSDは 小さく, 加速度のパターンは類似していることを示して いた。

各方向別においては，前後方向ではHC付近に「減速 $\rightarrow$ 


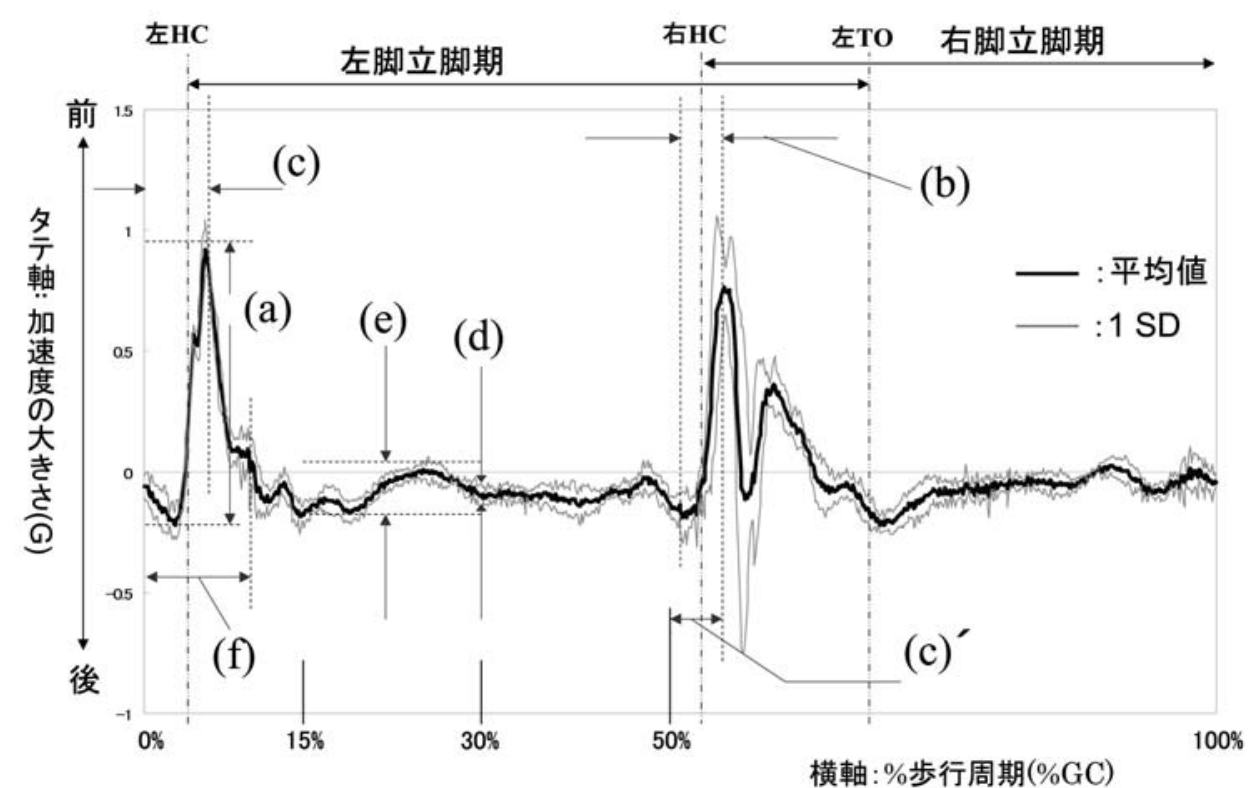

図1 分析ポイントー前後方向（X軸）を例として $\mathrm{HC}$ : 踵接地 (heel contact) $\mathrm{TO}$ : 足先離地（toe off）

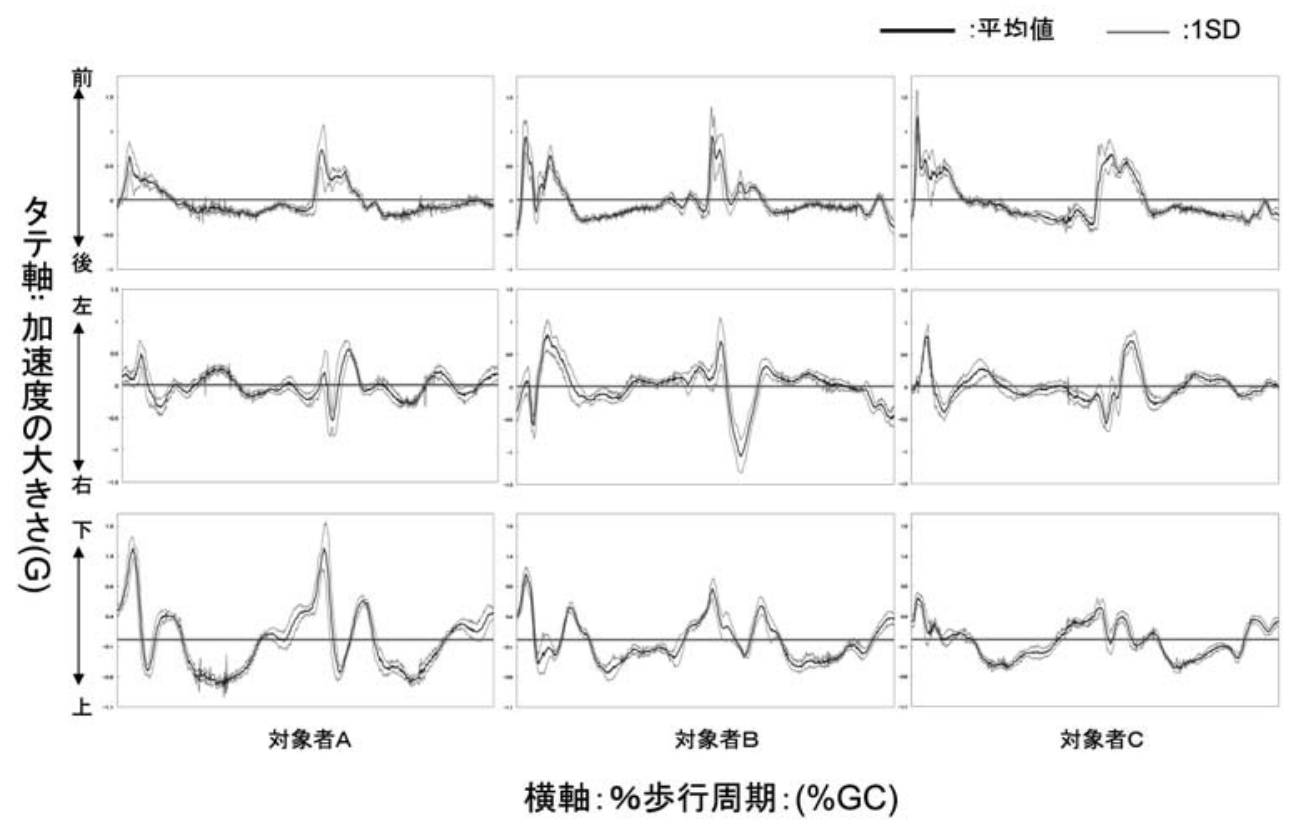

図2 若年者5歩行周期平均の事例

上段横1列に前後方向（X軸），中段は左右方向（Y軸），下段は上下方向（Z軸）

ピーク 減速」という一連の共通した振幅のパターンを 示し, ピークの大きさとタイミングも同じ傾向を示した。 また, 左右足のピーク間における\%GC内では加速度の大 きな変化は見られず，加速度の大きさは0G付近に位置し ていた。左右方向においてもHC付近にピークを示すが,
対象者間に異なる加速度パターンを示した。また，上下 方向では左足, 右足ともピークに2峰性の振幅が示され た。左右，上下方向とも左足と右足のピーク間における \%GC内では加速度の大きさは著しい変化を示し, 対象者 間により各パターンに差違が認められた。 


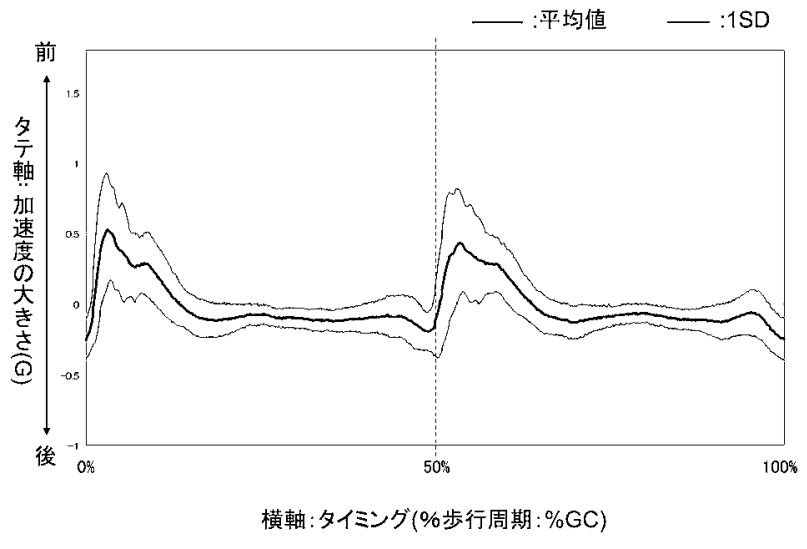

図3 若年者20名平均值（前後方向）

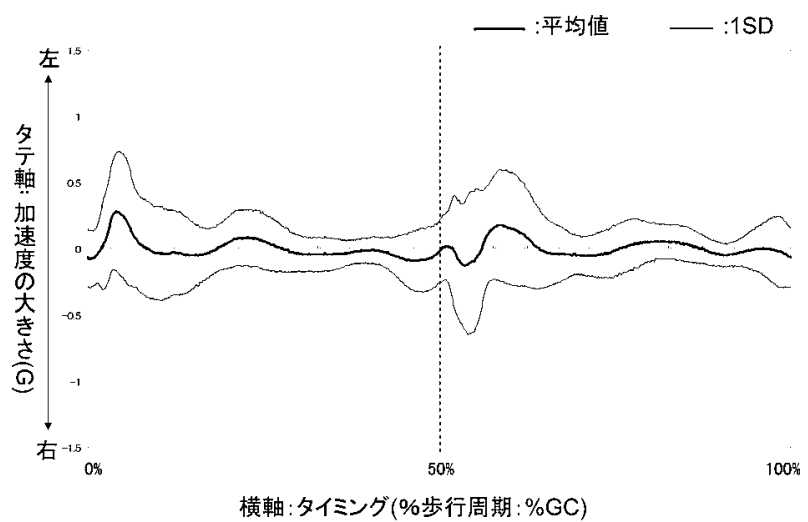

図4 若年者20名平均值（左右方向）

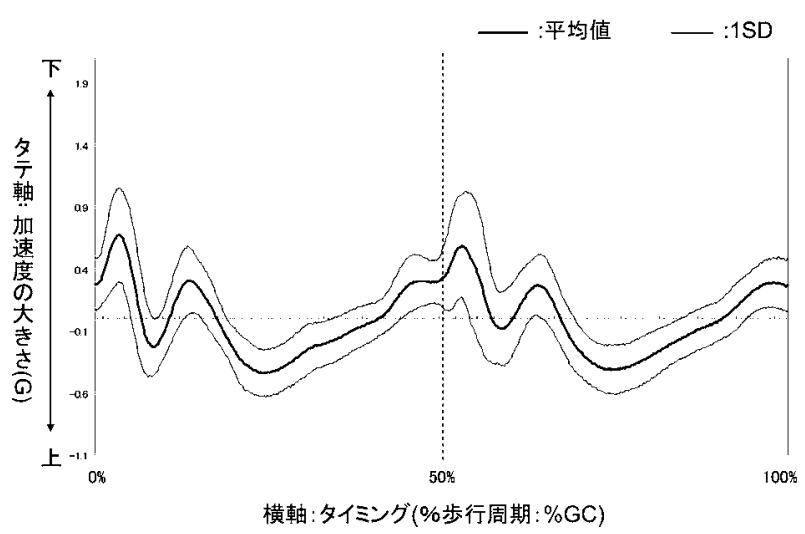

図5＼cjkstart若年者20名平均值（上下方向）
各3方向の加速度データにおける波形線の軌道パター ンには共通性がある。しかし，個人のデータでは，ピー クの大きさ，時間的なタイミングに差違が認められた。

2. 対象者別平均と 20 名平均の分析

図1における分析ポイントと照合し，対象者別の5歩周 期平均（図2）と20名平均值（図3，4，5）による各方向 の加速度データの特徵を分析した結果を以下に示す。

(1) 前後方向 (X軸)

前後方向の対象者別の平均とSD（図2）から，(a) の $\mathrm{HC}$ 前後の振幅は, 前方向 $(+\mathrm{G})$ に大きな加速を示した。 個人差はあるがピークに至るパターン傾向は各対象者で ほぼ一致していた。（b）の右足のピークタイミングは50 $\%$ 付近で一度後方向へ減速し再び前方向へ大きく加速し てピークに至った。各対象者とも一致したタイミングを 示していた。（c）の左右差はほとんどの対象者で認めら れなかった。（d）の30\%GC分散は低值を示した。また， （e）の15３0\%GC加速度変化は小さかった。（f）のおけ る減速タイミングも $15 \%$ GC付近で全ての対象者に認め られた。

次に20名分を平均化したものを図3に示した。加速の振 幅ピークは若干の平坦化を示した。また，全ての歩行周 期においてSDは平均化により大きくなった。平均化によ る加速の特徴パターンは各対象者が示す特徴を視覚的に 反映していた。

以上より, 加速度の大きさのピーク，加速変化を示す \%GCのタイミングが共通して出現されることから, 若者 の前後方向の加速度データには個人差は少なく，ほぼ共 通した特徴的パターンを示すことが明らかとなった。

(2) 左右方向 (Y軸)

左右方向の対象者別の平均とSD（図2）から，(a) は 前後方向に比べ各対象者間に差違が認められた。（b）は 各対象者とも前後方向より遅れて示された。（c）の差は 認められなかった。また，（d）は低值を示した。（e）の 大きさおよび（f）のタイミングにおいては各対象者によ り大きな差違が認められた。

次に20名分を平均（図4）したものでは，加速度データ が極端な平坦化を示し, 各対象者の特徴を反映する特徴 は認められなかった。以上より, 若年者の左右方向にお ける加速度データの分析ポイントには対象者内の差は少 なく, ほぼ共通した特徴的なパターンを示していた。し かし, 各対象者間には大きな差を示す分析ポイントが存 在することが明らかとなった。

(3) 上下方向 ( $Z$ 軸)

上下方向の対象者別の平均とSD（図2）から，(a)の振 
幅の大きさに左右方向と同様，各対象者間に差違が認め られた。また，2峰性の振幅パターンを全ての対象者で示 した。(b) では50\%GC付近に反対側 (右足) の下方向 $(+\mathrm{G})$ ピークを示した。(c)の差は認められなかった。また，(d) は低值を示した。（e）は各対象者とも上方向（-G）に大 きな加速度の変化を示した。その值の大きさは各対象者 間に差違が認められた。（f）の減速タイミング（上方向） は20各対象者ともほぼ20\%GC付近に一致していた。

次に20名分を平均（図5）したものでは，平均化によ り加速度データが若干平坦化を示したが，2峰性のピーク による振幅パターンは平均值，SDともに明確に示した。 しかし, 全\%GC内の分散は大きく示した。以上より若年 者の上下方向は共通的な加速を下方向 $(+\mathrm{G})$ も上方向

(-G) もピークおよびタイミングにおいて認められる が，加速度データの振幅の大きさに個人差が認められ， 分散を大きく示すことが明らかとなった。

以上, 各3方向の分析結果から対象者別, 対象群の平均 による共通した特徴的パターンとして明確に示す方向は 前後方向であることが確認された。しかも, 対象者のデー タを平均化しても, 個人のパターンの特徵がほぼ反映さ れることが明らかとなった。また，上下方向も全\%GC内 において大きな分散を示すものの, 各対象者の共通した 特徴的なパターンを示す傾向が認められた。

\section{IV. 考 察}

加速度データの結果から, 3方向とも対象者内ではデー タのばらつきは小さく, ピークを示す\%GCの位置, 大き さにおいて類似していた（図2）。歩行は高度に自動化さ れた運動であり, 健常成人では一定のパターンが反復・ 連続したもので構成されているものである11)ということ が加速度データからも裏付けられ, 歩行の恒常性が確認 できた。各対象者間においては，対象者によって振幅の ピーク值や平均值の大きさに違いが認められたが, 加速・ 減速を示すタイミングはほぼ一致していた。以上より3方 向に共通している点は, HC後に明らかな振幅のピークが 認められること, 反対側の右HCのタイミングは $50 \% \mathrm{GC}$ 付近にあること，左右対称であることであり，これらが 健常成人による正常歩行の特徴パターンと判断される。

次に, 各対象者の加速度データを各3方向別に分析した 結果, 前後方向では対象者内においても, 各対象者間の 比較においても分析ポイントである振幅の大きさ (a), 右 足のピークタイミング (b) , 左右差 (c) ，30\%GC分散 (d)，15〜30\%GC加速度変化（e），減速タイミング (f) にはパターンによる差違は無く, 類似した特徵が認めら
れた。また，平均化しても個人の特徵を反映するパター ンを示していた。

窪田7)や小野㠃 ${ }^{12)}$ は, 左右方向に対しては加速度が複雑 に変化するために評価の指標から除外しているが，本研 究では各軸の特徴的パターンを同定するために，検討す ることとした。その結果, 左右方向ではHC付近の振幅の 大きさに対象者間で差違が認められた。しかし，対象者 内では（b）が類似して出現すること，(c)（d）に差違を 示さないことより左右方向の特徵が認められた。但し, 20名のデータを平均化したところ顕著な平坦化を示し た。これは各対象者間において大きさやタイミングに差 違があることによるものといえる。

上下方向はHC付近の振幅の大きさ（a），15～30\%GC 加速度変化（e）に対象者間の差違が認められた。（e）に おいては左右の加速ピーク間に示す上方向 $(-\mathrm{G})$ への パターンに対象者間の差違が顕著であった。しかし, 各 対象者間で共通してHC付近に上下方向の特徵である2峰 性の振幅ピークが出現すること帛, 左右対称 (c) である ことにより, 上下方向の加速度データの逸脱ではなく, むしろ，これが特徵パターンを示すものと解釈される。

また，左右，上下方向の分析ポイントによって各対象 者間により加速度パターンに差違がみられたが，対象者 内には明らかな差は認められなかった（図3）。しかし， 20名の平均值による加速度データは平坦化を示してお り, 平均化したデータから個人データの特徵的パターン を同定することはできないことが明らかとなった（図4)。 一方, 前後方向は各分析のポイントで対象者内, 各対象 者間とも加速度データの傾向に差違がなく, 個人差が データに反映されない特徴を示した。そして, これらの 特徵には性差も認められなかった。

$\mathrm{Menz}^{9}$ ) は, 骨盤部と頭部に加速度計を装着し3方向を同 時計測した結果，対象者内にみられる加速度の共通する 特徵的パターンを示すものは上下方向であり, 前後方向, 左右方向においては骨盤部と頭部の加速度に共通する特 徽的パターンを示さないと報告している。しかし本研究 においては前述のごとく, 加速度データの同定を検討し た結果, 各対象者間の比較により前後方向に共通した特 徵的パターンを示し, 若年者 20 名平均による加速の傾向 もこれと類似した特徴的なパターンが認められた。よっ て, 通常歩行時の加速度データの特徵的パターンを各個 人で比較する場合，前後方向の年代群の平均波形図を用 いて分析対象とすることが有用であると判断された。一 方，左右方向は顕著な平坦化を示すこと，上下方向は平 均化したデータにのみ特徵的パターンを示し，\%GC内で は全てSDが大きくなることから, 臨床的に応用するには 
不十分であると解釈された。

以上より，若年者を基点とする健常成人において，各 3方向による加速度の特徵的パターンの定義は次のよう に要約される。

1. 前後方向 $(X$ 軸)

左HC前後に前方向に加速し，その後ピークから15\%付 近まで減速がみられる。加速度データが後方向 $(-\mathrm{G})$ 一 変化した以降は際立った加速および減速はみられない。 右HC（50\%GC付近）からも同じ加速度データの傾向を 示す。

\section{2. 左右方向 (Y軸)}

左HC直前に左方向に加速し，その後右方向へ加速を示 す。その後反対側（右）のHC後のピークが出現するまで 際立った加速・減速はみられない。右HC（50\%GC付近） からは反対の加速度データの傾向を示寸。

3. 上下方向 (Z軸)

左HC直前に下方向 $(+\mathrm{G})$ に2峰性の加速をしてから 減速をし，その後上方向（-G） へ加速する。右HC（50 \%GC）からは同じ加速度データの傾向を示す。

加速度データを正規化し，本研究にて着眼した（a）〜 (f) の分析ポイントの照合から検討することによって, 個 人の共通した特徵的パターンが存在することが明らかに なった。

\section{V. 結 論}

本研究では，正規化した若年者の歩行時加速度データ より共通する特徴的パターンを同定することを目的とし た。その結果，加速度計を用いて測定された健常若年者 による歩行時の骨盤加速度には，各対象者および対象者 全体の平均值に共通した特徵的なパターンが存在するこ とが明らかとなった。
通常歩行時の加速度データの特徵パターンを個人間で 比較する場合には，特に前後方向の波形を分析対象とす ることが有用であるといえる。

\section{引用文献}

1) 西野一郎, 緒方公介, 野見山宏・他 : 歩行解析における加速 度計の有用性. 整形外科と災害外科, 1993, 42(3): 132-134.

2) 小田典雄，千野直一，山崎信寿：マイコンを応用した簡易歩 行分析. 総合リ八, 1998, 10(2): 245-249.

3）田中尚文，園田 茂，松岡慶裕・他：小型加速度計による歩 行分析の再現性および妥当性の検討. リ八医学，1996, 33(8): 549-553.

4) Nelson WL: Physical principle for economies of skilled movements. Biol. Cybern, 1983, 46: 135-147.

5) Gage H: Accelerographic analysis of human gait. American Society for Mechanical Engineers, 1964 ,

6) Gary LS, Jasbir SA, Richard CJ: Accelerographic analysis of several types of walking. American J of Physical Medicine, 1971, 50(6): 285-300.

7) 窪田俊夫, 山口恒弘, 中川武夫・他 : 片麻痺歩行の安定性に 関する定量的評価方法について. 総合リ八，1986, 14(2): 123128.

8) Bernard A, Gilles B, Claude T, et al.: Reference data for normal subjects obtained with an accelerometric device. Gait and Posture, 2002, 16: 124-134.

9) Hylton BM, Stephen RL, Richard CF: Acceleration patterns of the head and pelvis when walking on level and irregular surfaces. Gait and Posture, 2003, 18: 35-46.

10) 木藤伸宏, 島澤真一, 弓削千文・他 : 加速度センサを用いた 変形性膝関節症の歩行時下腿運動の解析. 理学療法学, 2004, 31(1): 86-94.

11) 中村隆一, 齋藤 宏 : 基礎運動学 第5 版. 医歯薬出版, 東 京, 2000, pp333-334.

12) 小野㟝晃 : 脳卒中片麻痺における足関節機能再建術の評価. リ八医学，1993, 30(2): 127-137. 